\title{
Screening of 20 Pantanal Wetland Plants for Anti-Candida Activity using HPLC-DAD-MS/MS and Bioautography to Characterize Active Compounds
}

\section{(ㄷ) (i) (우)}

\author{
Authors \\ Daniela Z. de Brito"\#, Nadla S. Cassemiro2\#, Jeana M. E. de Souza², Geraldo A. Damasceno-Junior ${ }^{3}$, Rodrigo J. Oliveira4, \\ Carlos A. Carollo ${ }^{2}$ D, Marilene R. Chang ${ }^{1}$
}

\section{Affiliations}

1 Laboratory of Microbiological Research, Faculty of Pharmaceutical Sciences, Food and Nutrition, Federal University of Mato Grosso do Sul, Campo Grande, Brazil

2 Laboratory of Natural Products and Mass Spectrometry - LaPNEM, Faculty of Pharmaceutical Sciences, Food and Nutrition, Federal University of Mato Grosso do Sul, Campo Grande, Brazil

3 Laboratory of Botany, Institute of Biosciences, Federal University of Mato Grosso do Sul, Campo Grande, Brazil

4 Center for Studies and Stem Cells, Cell Therapy and Toxicological Genetics - CeTroGen, Maria Aparecida Pedrossian University Hospital, Federal University of Mato Grosso do Sul, Campo Grande, Brazil

\section{Key words}

Antifungal, bioautography, Candida, podophyllotoxin, Brazilian wetlands

received 04.12 .2020

revised 20.04.2021

accepted 27.04.2021

\section{Bibliography}

Planta Med Int Open 2021; 8: e96-e103

DOI 10.1055/a-1494-1117

ISSN 2509-9264

(C) 2021. The Author(s).

This is an open access article published by Thieme under the terms of the Creative Commons Attribution-NonDerivative-NonCommercial-License, permitting copying and reproduction so long as the original work is given appropriate credit. Contents may not be used for commercial purposes, or adapted, remixed, transformed or built upon. (https://creativecommons. org/licenses/by-nc-nd/4.0/)

Georg Thieme Verlag KG, Rüdigerstraße 14,

70469 Stuttgart, Germany

\section{Correspondence}

Prof. Dr. Carlos Alexandre Carollo

Laboratory of Natural Products and Mass Spectrometry LaPNEM, Faculty of Pharmaceutical Sciences, Food and Nutrition, Federal University of Mato Grosso do Sul, Campo Grande,

79070-900 MS

Brazil

Tel.: + 55-67-33457366

carlos.carollo@ufms.br

\section{ABSTRACT}

The Pantanal wetland harbors a rich flora with uncharted pharmacological potential. This study evaluated 20 Brazilian Pantanal plants against Candida albicans, C. parapsilosis, C. tropicalis, and $C$. krusei. Fungal susceptibility was determined by agar diffusion and broth microdilution; active compounds were identified by bioautography and HPLC-DAD-MS/MS. Sesbania virgata, Polygala molluginifolia, and Cantinoa mutabilis extracts and their chloroform and ethyl acetate (EtOAc) fractions exhibited the best activity against all Candida species tested. The EtOAc fraction of $P$. molluginifolia proved to be more efficient in inhibiting C. parapsilosis and C. krusei growth (Minimum inhibitory concentration of 125 and $62.5 \mu \mathrm{g} / \mathrm{mL}$, respectively). Bioautography of this fraction revealed two active bands, characterized by HPLC-DAD-MS/MS as a mixture of podophyllotoxin derivatives blumenol, besides some flavonoids. This work demonstrated antifungal potential of $P$. molluginifolia podophyllotoxin derivatives and the versatility of bioautography with HPLC-DAD-MS/MS to identify the bioactive compounds. 


\section{Introduction}

Dermatophytes and yeasts of the genus Candida are the primary cause of superficial fungal infections and still among the most prevalent skin, hair, and nail disorders. Candida species are also responsible for mucous-membrane infections, affecting several organs and tissues $[1,2]$. Recent decades have seen a substantial increase in systemic and bloodstream infections associated with high morbidity and mortality rates, particularly in immunocompromised patients and those undergoing invasive procedures $[3,4]$.

In general, critically ill patients, such as those with an immature immune system or immune senescence, are at high risk of developing invasive Candida infection [2, 3, 5]. Five Candida species cause over $80 \%$ of candidemia cases: C. albicans, C. glabrata, C. parapsilosis, C. tropicalis, and C. krusei $[2,6,7]$.

The first-line drugs for the treatment of invasive candidiasis are echinocandins and azoles [3]. One of the most widely used antifungals in medical practice is fluconazole. However, Candida krusei is intrinsically resistant to this antifungal, and the resistance to this azole has also been reported in other Candida species [2,3]. More recently, the emergence of multidrug-resistant Candida auris in hospitals has caused panic worldwide $[3,4]$. In this context, plants as an abundant source of novel active compounds, including antifungal agents, may be used as prototypes to develop new drugs [8].

The tropical wetland Pantanal, located in central-western Brazil, is known for the rich flora with unexplored pharmacological potential [9]. This biome is a unique ecosystem marked by regular seasonal flooding, and vast plant diversity comprises roughly 3500 species across some phytogeographic regions, including vegetation of Seasonal Semideciduous Forest, Amazon Forest, Chaco, and Cerrado [10].

Thus, the present study explores 20 plant species, commonly found in the Pantanal, for their antifungal activity against four Candida species using agar diffusion, broth microdilution, bioautography, and HPLC-DAD-MS/MS to find new antifungal agents.

\section{Results}

Extracts of all tested species exhibited antifungal activity against at least one Candida sp. on the disk diffusion test. Only the crude extracts of Sesbania virgata, Polygala molluginifolia, and Cantinoa mutabilis proved to be active against all Candida species tested in both concentrations ( $\vee$ Table $\mathbf{1}$ ). $\triangleright$ Table $\mathbf{2}$ shows the diameters of inhibition halos promoted by fractions of S. virgata, P. molluginifolia, and $C$. mutabilis fractions, where we can observe that exclusively $\mathrm{CHCl}_{3}$ and EtOAc fractions were active.

- Table 3 shows the Minimal Inhibitory Concentrations (MIC) of fractions that demonstrated activity against Candida species in antifungal susceptibility tests based on microdilution. Minimum fungicidal concentration (MFC) of the EtOAc fraction of $P$. molluginifolia (Pm-EtOAC) was $125 \mu \mathrm{g} / \mathrm{mL}$ against C. parapsilosis and $62.5 \mu \mathrm{g} /$ $\mathrm{mL}$ against $C$. krusei, coinciding with MIC values. MFC of the $\mathrm{CHCl}_{3}$ fraction of the same plant species was $500 \mu \mathrm{g} / \mathrm{mL}$ against $C$. parapsilosis and $1000 \mu \mathrm{g} / \mathrm{mL}$ against $C$. krusei.

The Bioautography of the Pm-EtOAc fraction revealed two active bands, which did not separate well, against $C$. parapsilosis and C. krusei ( $\triangleright$ Fig. 1). These bands were isolated on a preparative TLC and analyzed in the HPLC-DAD-MS/MS. In the bands ( $\vee$ Fig. 1b), lignans derived from podophyllotoxin, megastigmanes, and flavonoids mixture were identified; these classes of compounds are already reported in some species of Polygala [11-18].

The upper and lower bands ( $\vee$ Fig. $\mathbf{1 b}$ ) were not well separated by preparative TLC. They revealed two compounds in common (compounds 2 and 12), reflecting the low-resolution power of the chromatographic system. These compounds were identified by HPLC-DAD-MS/MS ( $\vee$ Table 4). Peaks 1, 2, 3, and 4 did not absorb in the monitored UV region (240-800 nm) and showed a similar fragmentation profile, identified as belonging to the megastigmane class. Compounds 1 and $3\left(\mathrm{~m} / z 385[\mathrm{M}-\mathrm{H}]^{-}, \mathrm{C}_{19} \mathrm{H}_{30} \mathrm{O}_{8}\right)$ were identified as isomers of blumenol hexoside [19]. The $\mathrm{m} / \mathrm{z} 205$ fragment refers to the loss of a hexosyl group observed for compound 1 . Compounds 2 and $4\left(\mathrm{~m} / \mathrm{z} 387\right.$ [MH], $\left.\mathrm{C}_{19} \mathrm{H}_{32} \mathrm{O}_{8}\right)$ displayed the presence of two additional hydrogens in relation to 1 and $3 ; \mathrm{m} / \mathrm{z} 207$ was relative to the loss of a hexosyl group. Based on this data, it was possible to identify them as dihydroblumenol hexoside isomers, according to data reported by Schliemann et al. [20].

Compounds 5, 6, 8, and 10 exhibit a UV spectrum compatible with a flavonol group, compounds 5, 8, and $10(\mathrm{~m} / \mathrm{z} 593[\mathrm{M}-\mathrm{H}]$;, $\mathrm{C}_{27} \mathrm{H}_{30} \mathrm{O}_{15}$ ) were identified as a flavonol-O-dihexoside, according to the literature [17, 21, 22]. Peak $6 \mathrm{~m} / \mathrm{z} 463.0864$ [M-H]'is compatible with a quercetin-O-hexoside, based on the ion at $\mathrm{m} / \mathrm{z}$ 300.0260 relative to the loss of the hexosyl group [23].

Peaks 11, 12, 13 and 14 showed $\mathrm{m} / \mathrm{z} 531.1495[\mathrm{M}-\mathrm{H}]^{-}, \mathrm{m} / \mathrm{z}$ 561.1617 [M-H]', m/z 545.1630 [M-H]' and m/z 575.1756 [M-H]', respectively. Their UV spectra and fragmentation profile were similar. Fragmentation of $\mathrm{m} / \mathrm{z} 561$ (12) generated m/z 399 [M-162]', referring to the loss of a hexosyl group. The $m / z 384, \mathrm{~m} / \mathrm{z} 369 \mathrm{frag}$ ments are from consecutive losses of methyl groups, and $\mathrm{m} / \mathrm{z} 341$ fragment refers to the loss of a $\mathrm{CO}$. This compound was identified as 4'-demethylpodophyllotoxin hexoside [24]. Peak 11 has a methoxy group less than compound 12 . The $\mathrm{m} / \mathrm{z} 354$ was formed by losing a hexosyl plus a methyl group; these data are consistent with those reported for podophyllotoxin hexoside derivative NC 370 [25]. Compound 13 has one oxygen less than 12; this was evidenced by the $m / z 383$ fragment relative to the hexosyl group's loss. Compound 14 has one methyl more than 12 , which forms the $\mathrm{m} / \mathrm{z} 396$ by losing a hexosyl plus a water group. These compounds were identified as 4'-demethylpodophyllotoxone hexoside (13) and desoxypodophyllotoxin hexosyl (14) by comparison with the data reported by Zhou et al. and Duan et al. [24, 25]. Finally, compound $15 \mathrm{~m} / \mathrm{z} 411.1078$ [M-H]', being identified as podophyllotoxone according to UV spectra and fragmentation reported by Zhou et al. and Meng-long et al. [24, 26].

\section{Discussion}

The highly diverse flora of the Pantanal biome remains scarcely studied, despite its potential for discovering pharmaceutical products. Here we demonstrate the potential of these plants to develop new anti-Candida drugs, the screening of 20 species led to the detection of antifungal activity against at least one Candida species by all crude extracts. Studies have shown that a single plant species can exhibit different activity levels (sensitivity) in vitro, depending on the Candida species targeted in tests [27]. 


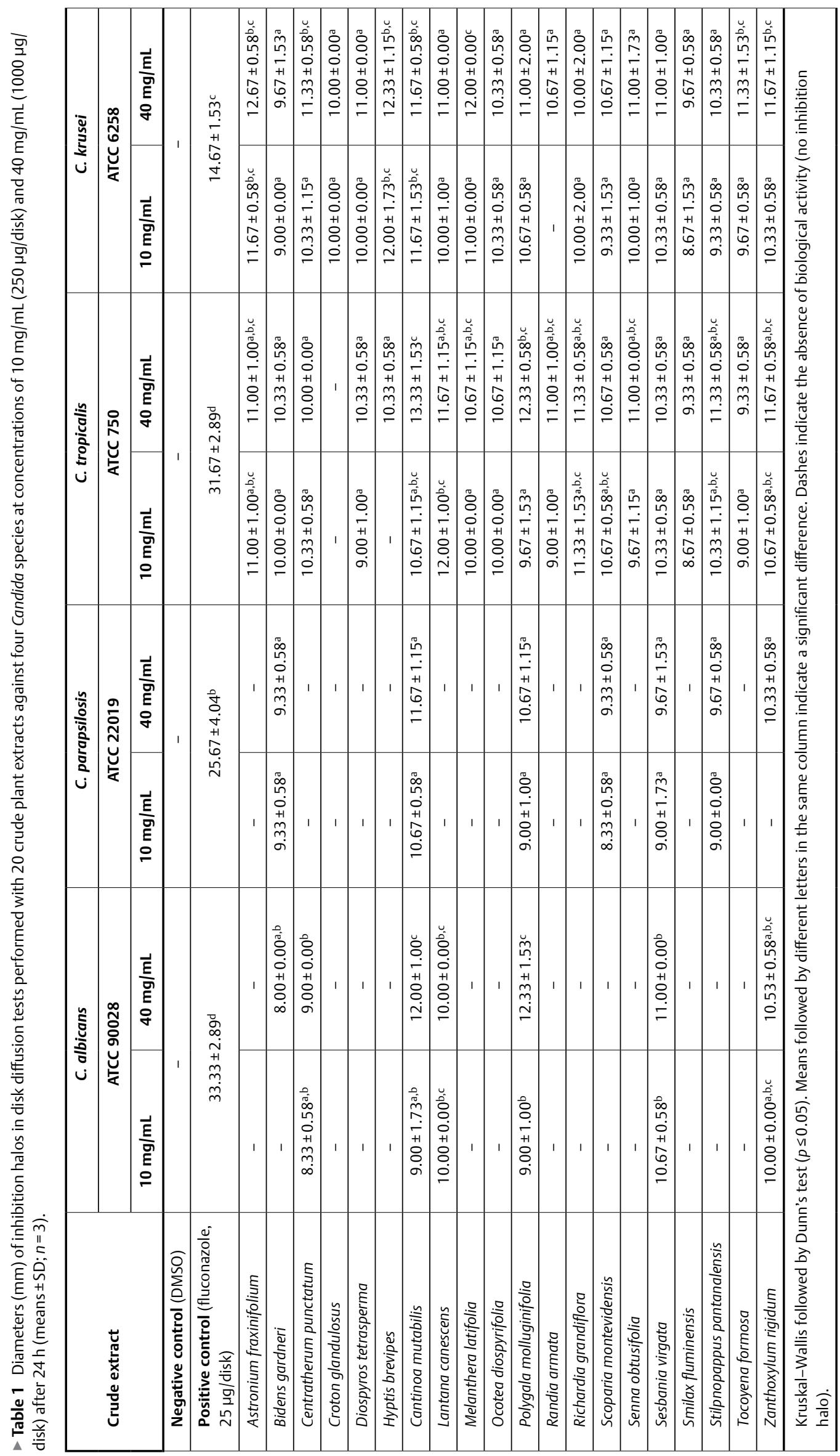


- Table 2 Diameters $(\mathrm{mm})$ of inhibition halos in the disk diffusion test performed against all Candida species using fraction concentrations of $10 \mathrm{mg} / \mathrm{mL}$ $(250 \mu \mathrm{g} /$ disk) and fluconazole at $25 \mu \mathrm{g} /$ disk after $24 \mathrm{~h}$ (means $\pm \mathrm{SD} ; n=4$ ).

\begin{tabular}{|c|c|c|c|c|c|}
\hline Extract & Fraction & $\begin{array}{l}\text { C. albicans } \\
\text { ATCC } 90028\end{array}$ & $\begin{array}{l}\text { C. parapsilosis } \\
\text { ATCC } 22019\end{array}$ & $\begin{array}{l}\text { C. tropicalis } \\
\text { ATCC } 750\end{array}$ & $\begin{array}{l}\text { C. krusei } \\
\text { ATCC } 6258\end{array}$ \\
\hline \multicolumn{2}{|c|}{ Negative control (DMSO) } & - & - & - & - \\
\hline \multicolumn{2}{|c|}{ Positive control (fluconazole) } & $34.75 \pm 3.69^{b}$ & $26.75 \pm 3.95^{\mathrm{b}}$ & $30.25 \pm 3.67^{b}$ & $16.50 \pm 2.38^{b}$ \\
\hline \multirow{5}{*}{ Sesbania virgata } & $\mathrm{Hx}$ & - & - & - & - \\
\hline & $\mathrm{CHCl}_{3}$ & $11.00 \pm 0.00^{\mathrm{a}, \mathrm{b}}$ & $11.00 \pm 0.82^{\mathrm{a}, \mathrm{b}}$ & $10.75 \pm 0.50^{\mathrm{a}, \mathrm{b}}$ & $10.75 \pm 0.96^{\mathrm{a}, \mathrm{b}}$ \\
\hline & EtOAc & $10.75 \pm 0.50^{\mathrm{a}, \mathrm{b}}$ & $10.75 \pm 0.50^{\mathrm{a}}$ & $10.00 \pm 0.00^{\mathrm{a}}$ & $10.25 \pm 0.50^{\mathrm{a}}$ \\
\hline & EtOH & - & - & - & - \\
\hline & $\mathrm{EtOH} / \mathrm{H}_{2} \mathrm{O}$ & - & - & - & - \\
\hline \multirow{5}{*}{ Polygala molluginifolia } & $\mathrm{Hx}$ & - & - & - & - \\
\hline & $\mathrm{CHCl}_{3}$ & $10.50 \pm 0.58^{\mathrm{a}}$ & $11.00 \pm 0.00^{\mathrm{a}, \mathrm{b}}$ & $11.50 \pm 1.29^{\mathrm{a}, \mathrm{b}}$ & $11.00 \pm 0.00^{\mathrm{a}, \mathrm{b}}$ \\
\hline & EtOAc & $11.75 \pm 0.96^{\mathrm{a}, \mathrm{b}}$ & $12.00 \pm 0.00^{\mathrm{b}}$ & $12.75 \pm 1.71^{\mathrm{a}, \mathrm{b}}$ & $13.00 \pm 0.82^{b}$ \\
\hline & EtOH & - & - & - & - \\
\hline & $\mathrm{EtOH} / \mathrm{H}_{2} \mathrm{O}$ & - & - & - & - \\
\hline \multirow{5}{*}{ Cantinoa mutabilis } & $\mathrm{Hx}$ & - & - & - & - \\
\hline & $\mathrm{CHCl}_{3}$ & $11.00 \pm 0.00^{\mathrm{a}, \mathrm{b}}$ & $12.00 \pm 0.82^{\mathrm{a}, \mathrm{b}}$ & $12.50 \pm 0.58^{\mathrm{a}, \mathrm{b}}$ & $11.50 \pm 1.29^{a, b}$ \\
\hline & EtOAc & $11.75 \pm 0.50^{\mathrm{a}, \mathrm{b}}$ & $11.75 \pm 0.50^{\mathrm{a}, \mathrm{b}}$ & $13.50 \pm 1.29^{b}$ & $11.75 \pm 0.96^{\mathrm{a}, \mathrm{b}}$ \\
\hline & EtOH & - & - & - & - \\
\hline & $\mathrm{EtOH} / \mathrm{H}_{2} \mathrm{O}$ & - & - & - & - \\
\hline
\end{tabular}

- Table 3 Minimum inhibitory concentrations of fractions exhibiting activity against all Candida species.

\begin{tabular}{|c|c|c|c|c|}
\hline \multirow{2}{*}{ Plant and solvent } & \multicolumn{4}{|c|}{ Candida spp. (MIC, $\mu \mathrm{g} / \mathrm{mL}$ ) } \\
\hline & C. albicans & C. tropicalis & C. parapsilosis & C. krusei \\
\hline \multicolumn{5}{|l|}{ Sesbania virgata } \\
\hline $\mathrm{CHCl}_{3}$ & $\geq 2000$ & $\geq 2000$ & $\geq 2000$ & $\geq 2000$ \\
\hline EtOAc & $\geq 2000$ & $\geq 2000$ & $\geq 2000$ & $\geq 2000$ \\
\hline \multicolumn{5}{|l|}{ Polygala molluginifolia } \\
\hline $\mathrm{CHCl}_{3}$ & $\geq 2000$ & $\geq 2000$ & 500 & 500 \\
\hline EtOAc & $\geq 2000$ & $\geq 2000$ & 125 & 62.5 \\
\hline \multicolumn{5}{|l|}{ Cantinoa mutabilis } \\
\hline $\mathrm{CHCl}_{3}$ & $\geq 2000$ & $\geq 2000$ & $\geq 2000$ & $\geq 2000$ \\
\hline EtOAc & $\geq 2000$ & $\geq 2000$ & $\geq 2000$ & $\geq 2000$ \\
\hline Fluconazole (control) & 0.5 & 0.5 & 2 & 16 \\
\hline
\end{tabular}

Different methodologies have been proposed to determine the antifungal activity of natural products against Candida species [2830], and has been the Disk diffusion the most used. Disk diffusion results showed that almost all crude extracts tested were active against the Candida ATCC strains, C. tropicalis and C. krusei, and seven proved active against $C$. albicans and $C$. parapsilosis ( $\triangleright$ Table 1 ). Extract concentration plays little or no role in antifungal effectiveness, as shown by the small difference between the diameters of inhibition halos obtained using 10 and $40 \mathrm{mg} / \mathrm{mL}$ concentrations ( Table 1).

No information is available on the antimicrobial activity of medium/high polarity secondary metabolites of S. virgata, P. molluginifolia, and C. mutabilis, which proved effective for inhibiting yeast growth in the disk diffusion test in the present study. S. virgata in- hibits filamentous fungi through the mediation of FP1-A protein [31].

In the literature, crude extracts of Hyptis albida and $\mathrm{H}$. verticillata produced, respectively, 4 and $7 \mathrm{~mm}$-wide inhibition halos in agar diffusion tests against C. albicans [32]. More recently, low MIC values and good antifungal activity against $C$. krusei and Crypyococcus neoformans have been reported for $H$. crenata fractions [32]. In our study, although C. mutabilis promoted inhibition halos of 7-14 mm in diameter, depending on extract concentration and Candida species MIC was high, suggesting an absence or weak activity. The same difference was also observed for the EtOAc and $\mathrm{CHCl}_{3}$ fractions of S. virgata and C. mutabilis.

Disk diffusion is commonly used as a pre-test due to its straightforwardness and low cost; however, some factors have to be con- 


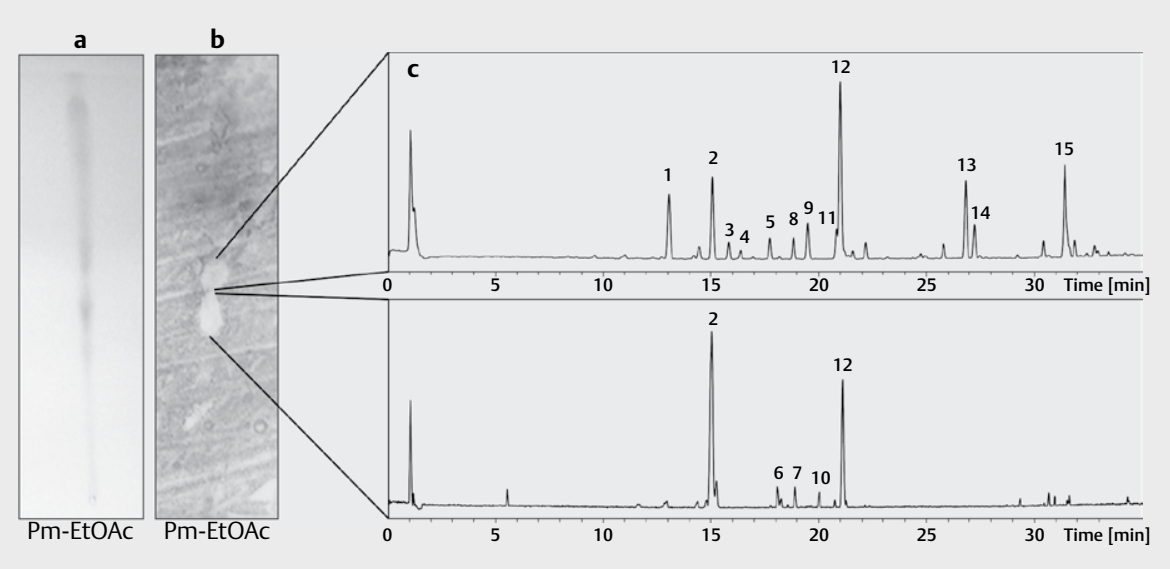

- Fig. 1 TLC of the EtOAc fraction of P. molluginifolia. b Bioautography of the EtOAc fraction of $P$. molluginifolia revealed two activity bands against C. parapsilosis and C. krusei. $\mathbf{b}$ High-performance liquid chromatography-mass spectrometry chromatographic profile spectra of bioautography active bands. 1: blumenol hexoside; 2: dihydroblumenol hexoside; 3: blumenol hexoside; 4: dihydroblumenol hexoside; 5: flavonol-O-dihexoside; 6: quercetin-O-hexoside; 7: unknown; 8: flavonol-O-dihexoside; 9: unknown; 10: flavonol-O-dihexoside; 11: podophyllotoxin hexoside derivative NC 370; 12: 4'-demethylpodophyllotoxin hexoside; 13: demethylpodophyllotoxone hexoside: 14: podophyllotoxin hexoside; 15: podophyllotoxone

sidered since studies have shown that culture medium composition influences extract activity and those natural compounds with good diffusion coefficients. Thus, weak antimicrobial compounds can penetrate the medium and, even in small amounts, inhibit growth. Additionally, the volume and $\mathrm{pH}$ of the medium, type of microorganism, extract volatility, and size and absorption capacity of paper disks may influence test results [29,33].

Serial broth microdilution yields better results and is regarded as the standard method for evaluating natural products. However, unknown active compounds require more than one method for testing their antimicrobial activity [29].

Polygala is the largest genus of the Polygalaceae family (over 1000 species and worldwide distribution). Antifungal activity in Polygala spp. has been the subject of few reports [28, 34], and no studies have been found for the anti-candida activity of $P$. molluginifolia. The low MIC values obtained for the $\mathrm{CHCl}_{3}$ and EtOAc fractions of $P$. molluginifolia against $C$. parapsilosis and $C$. krusei suggest an excellent antifungal activity, a promising result, considering that C. parapsilosis is one of the primary agents of bloodstream infection, particularly in children and in patients using intravascular devices [7, 35]. C. krusei has been isolated from several immunocompromised patients with cancer or neutropenia $[6,34]$ and is intrinsically resistant to fluconazole, a drug often used against systemic fungal infection [36].

The bioautography of Pm-EtOAc allowed the isolation of the fraction's active compounds, three main classes of metabolites were identified by HPLC-DAD-MS/MS: lignans, megastigmanes, and flavonoids. The presence of these metabolites has already been reported in the literature in a few species of Polygala, such as lignans derived from podophyllotoxin found in P.macradenia, P. paenea, and $P$. polygama $[11,12,15]$, megastigmane in $P$. tenuifolia and $P$. hongkongensis $[14,16]$ and flavonoids in $P$. hongkongensis and P. sibirica $[13,18]$.

In our study, glycosylated megastigmane derivatives of blumenol and dihydroblumenol were identified. The absence of UV ab- sorption and the $\mathrm{m} / \mathrm{z} 205$ fragments for blumenol derivative and $\mathrm{m} / \mathrm{z} 207$ for dihydroblumenol allowed us to confirm the compounds. Other compounds detected in the two active bands belonged to the class of flavonoids (6, 11, and 13). Anti-Candida activity for flavonoids has already been well reported in the literature [37]. On the other hand, there are no reports in the literature of the antifungal activity of blumenol derivatives.

It is essential to highlight that besides the fact that several authors have shown that lignin derivatives have antifungal and antimicrobial activity $[38,39]$, no reports were found for podophyllotoxin derivatives, broadly known by their cytotoxic, anticancer, and antiviral activity [40].

Thus, this work demonstrated the disk diffusion test's high sensitivity and the importance of performing the MIC for extracts and active fractions; among the twenty plants studied, the best antiCandida activity was observed with the extracts of S. virgata, P. molluginifolia and $\mathrm{C}$. mutabilis in their fractions chloroform ( $\mathrm{fr}-\mathrm{CHCl} 3$ ) and ethyl acetate (fr-AcOEt) against C. albicans, C. parapsilosis, C. tropicalis and C. krusei. P. molluginifolia showed better performance in vitro, lower minimum inhibitory concentration to $C$. parapsilosis and C. krusei. The bioautography along with HPLC-DADMS/MS allowed us to identify the bioactive compounds in $P$. molluginifolia, revealing the antifungal potential of podophyllotoxin derivatives, the main compounds of the active bands. The observation of anti-Candida activity in $P$. molluginifolia is unprecedented and can be promising for the development of new antifungals, especially for treating infections caused by $C$. parapsilosis and C. krusei.

\section{Materials and Methods}

\section{Plant material}

The plants collected from the Pantanal wetland were identified by Prof. Geraldo A. Damasceno-Junior, and a voucher specimen was 


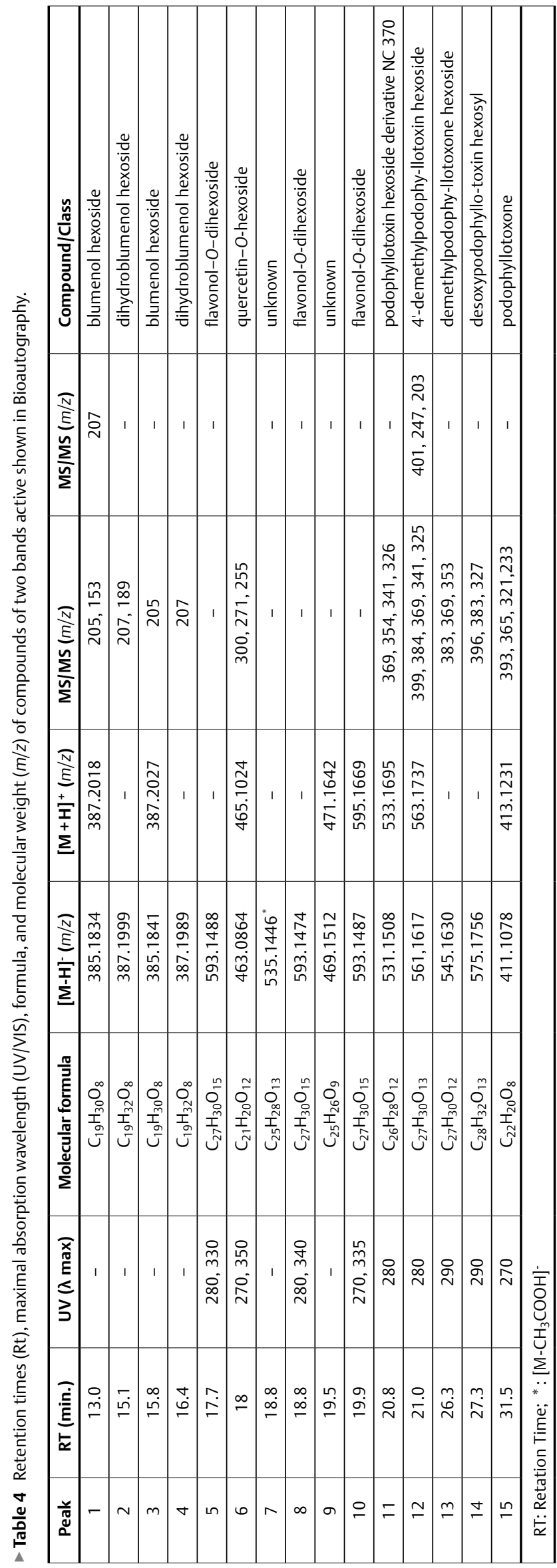

deposited at the CGMS Herbarium (SISBIO license 33165-2). - Table 5 lists the 20 species, along with coordinates of collection sites, parts used in the experiments, numbers of the exsiccate voucher, and yield of crude extracts.

\section{Preparation of extracts}

The samples were oven-dried, grounded, and then extracted with ethanol:water (7:3), as described by Richter et al. [41], in an ASE 150 pressurized solvent extractor (Dionex, USA) $(5 \mathrm{~mL}$ sample cartridges, 5 min static time program, $100^{\circ} \mathrm{C}, 60 \%$ rinse volume, 100 s purge time, two cycles), the extracts yields are in $>$ Table 5 The active extracts on the disk diffusion test were re-extracted with the same apparatus and solvents of gradient polarity (hexane, chloroform, ethyl acetate, ethanol, ethanol:water) to yield fractions.

\section{Antifungal susceptibility test}

Candida albicans (ATCC-90028), C. parapsilosis (ATCC-22019), C. krusei (ATCC-6258), and C. tropicalis (ATCC-750) strains from the American Type Culture Collection, were used for in vitro susceptibility testing.

\section{Disk diffusion test}

Initial screening for antifungal activity was based on disk diffusion [42]. The surfaces of culture plates were seeded with each Candida inoculum and covered with sterile filter paper disks $(6 \mathrm{~mm}$ in diameter) subsequently impregnated with $25 \mu \mathrm{L}$ of extract previously solubilized in dimethyl sulfoxide (DMSO) (Sigma-Aldrich, France). The concentrations used were $10 \mathrm{mg} / \mathrm{mL}(250 \mu \mathrm{g} /$ disk) and $40 \mathrm{mg} /$ $\mathrm{mL}(1000 \mu \mathrm{g} /$ disk $)$ for crude extracts and $250 \mu \mathrm{g} /$ disk for fractions. Fluconazole-impregnated disks ( $25 \mu \mathrm{g}$, Cecon, Brazil) were used as sensitivity controls. The assays were performed at least in triplicate.

\section{Minimum inhibitory concentration (MIC) using microbroth dilution}

The fractions with the highest activity in the disk diffusion tests were evaluated for MIC, following the guidelines of CLSI [43]. The extract concentration ranged from 31.25 to $8000 \mu \mathrm{g} / \mathrm{mL}$ and fluconazole from 0.25 to $64 \mu \mathrm{g} / \mathrm{mL}$ (reference control, Sigma Aldrich, France, Purity $\geq 98 \%$ ). MIC was defined as the lowest concentration of extract at which no fungal growth was observed after incubation. All testing was conducted in quadruplicate.

\section{Antifungal bioautography}

The bioautography assay was carried out as described by Rahalison et al. [44], with minor modifications. $100 \mu \mathrm{g}$ of $P$. molluginifolia EtOAc fraction (Pm-EtOAc) were applied to the silica gel plate (Macherey-Nagel, Germany) and subsequently eluted with EtOAc:MeOH: $\mathrm{H}_{2} \mathrm{O}$ (100:13.5:10). Liquefied SDA was poured onto the eluted TLC plates. After solidification, the yeasts were seeded and incubated at $35^{\circ} \mathrm{C}$ for $48 \mathrm{~h}$. Bioautograms were developed with a solution of piodonitrotetrazolium ( $2 \mathrm{mg} / \mathrm{mL})$.

\section{Isolation of active fractions from Pm-EtOAc by Preparative thin layer chromatography}

$50 \mathrm{mg}$ of the Pm-EtOAc were applied to the silica gel plate and subsequently eluted with EtOAc: $\mathrm{MeOH}: \mathrm{H}_{2} \mathrm{O}$ (100:13.5:10). Bands 
- Table 5 Taxonomic data coordinates of collection sites, parts used in the experiments, and yield of crude extracts.

\begin{tabular}{|c|c|c|c|c|c|}
\hline Species & Family & Coordinates & Part used & Voucher number & Yield (\%) \\
\hline Astronium fraxinifolium Schott ex Spreng & Anacardiaceae & $19^{\circ} 29^{\prime} 2 " \mathrm{~S} 57^{\circ} 2^{\prime} 16^{\prime \prime} \mathrm{W}$ & $\mathrm{T}+\mathrm{L}$ & 5198 & 20.02 \\
\hline Bidens gardneri Bak. & Asteraceae & $19^{\circ} 28^{\prime} 59^{\prime \prime} \mathrm{S} 57^{\circ} 2^{\prime} 16^{\prime \prime} \mathrm{W}$ & $\mathrm{AP}+\mathrm{L}$ & 5192 & 17.68 \\
\hline Centratherum punctatum Cass. & Asteraceae & $19^{\circ} 37^{\prime} 5^{\prime \prime S} 57^{\circ} 2^{\prime} 4 " \mathrm{~W}$ & $\mathrm{AP}+\mathrm{FL}$ & 5169 & 15.67 \\
\hline Croton glandulosus L. & Euphorbiaceae & $19^{\circ} 34^{\prime} 7 " \mathrm{~S} 57^{\circ} 1^{\prime} 15^{\prime \prime} \mathrm{W}$ & $\mathrm{AP}+\mathrm{FL}$ & 5186 & 14.08 \\
\hline Diospyros obovata tetrasperma Sw. & Ebenaceae & $19^{\circ} 29^{\prime} 2 " \mathrm{~S} 57^{\circ} 2^{\prime} 16^{\prime \prime} \mathrm{W}$ & $T+L$ & 5203 & 9.91 \\
\hline Hyptis brevipes Poit. & Lamiaceae & $19^{\circ} 34^{\prime} 8 " \mathrm{~S} 57^{\circ} 1^{\prime} 10^{\prime \prime} \mathrm{W}$ & $\mathrm{EP}+\mathrm{FL}$ & 5177 & 14.29 \\
\hline Cantinoa mutabilis (Rich.) Harley \& J.F.B.Pastore & Lamiaceae & $19^{\circ} 29^{\prime} 3 " \mathrm{~S} 57^{\circ} 2^{\prime} 15^{\prime \prime} \mathrm{W}$ & $A P+F L$ & 5191 & 13.61 \\
\hline Lantana canescens Kunth & Verbenaceae & $19^{\circ} 37^{\prime} 5 " \mathrm{~S} 57^{\circ} 2^{\prime} 4^{\prime \prime W}$ & $\mathrm{AP}+\mathrm{FL}$ & 5170 & 23.72 \\
\hline Melanthera latifolia (Gard.) Cabrera & Asteraceae & $19^{\circ} 34^{\prime} 36^{\prime \prime} \mathrm{S} 57^{\circ} 1^{\prime} 11^{\prime \prime W}$ & $\mathrm{AP}+\mathrm{FL}$ & 5172 & 14.66 \\
\hline Ocotea diospyrifolia (Meisn.) Mez & Lauraceae & $19^{\circ} 36^{\prime} 30^{\prime S} 57^{\circ} 2^{\prime} 8^{\prime \prime} \mathrm{W}$ & $\mathrm{T}+\mathrm{L}$ & 5213 & 18.93 \\
\hline Polygala molluginifolia A. St.-Hil. \& Moq. & Polygalaceae & $19^{\circ} 34^{\prime} 36^{\prime \prime S} 57^{\circ} 1{ }^{\prime} 10^{\prime \prime W}$ & $\mathrm{EP}+\mathrm{FL}$ & 5171 & 24.46 \\
\hline Randia armata (Sw.) DC. & Rubiaceae & $19^{\circ} 29^{\prime} 2 " \mathrm{~S} 57^{\circ} 2^{\prime} 16^{\prime \prime} \mathrm{W}$ & $T+L+F R$ & 5202 & 14.58 \\
\hline Richardia grandiflora (Cham. \& Schltdl.) Steud. & Rubiaceae & $19^{\circ} 34^{\prime} 8 " \mathrm{~S} 57^{\circ} 1^{\prime} 14^{\prime \prime} \mathrm{W}$ & $\mathrm{AP}+\mathrm{FL}$ & 5188 & 13.17 \\
\hline Scoparia montevidensis (Spreng.) R.E. Fr. & Plantaginaceae & $19^{\circ} 36^{\prime} 18^{\prime \prime S} 57^{\circ} 3^{\prime} 14^{\prime \prime W}$ & $\mathrm{AP}+\mathrm{FL}$ & 5209 & 14.37 \\
\hline Senna obtusifolia (L.) H.S. Irwin \& Barneby & Leguminosae & $19^{\circ} 34^{\prime} 9 " \mathrm{~S} 57^{\circ} 1$ '10"W & $A P+F L+F R$ & 5178 & 18.06 \\
\hline Sesbania virgata (Cav.) Pers. & Fabaceae & $19^{\circ} 37^{\prime} 5^{\prime \prime} \mathrm{S} / 57^{\circ} 2^{\prime} 4^{\prime \prime} \mathrm{W}$ & $\mathrm{T}+\mathrm{L}$ & 5168 & 21.34 \\
\hline Smilax fluminensis Steud. & Smilacaceae & $19^{\circ} 29^{\prime} 6^{\prime S} 57^{\circ} 2 ' 19 " \mathrm{~W}$ & $\mathrm{AP}+\mathrm{FL}$ & 5190 & 11.64 \\
\hline Stilpnopappus pantanalensis H. Rob. & Asteraceae & $19^{\circ} 29^{\prime} 0 " \mathrm{~S} 57^{\circ} 2^{\prime} 14 " \mathrm{~W}$ & $A P+L$ & 5195 & 14.97 \\
\hline Tocoyena formosa (Cham. \& Schltdl.) K. Schum. & Rubiaceae & $19^{\circ} 29^{\prime} 2 " \mathrm{~S} 57^{\circ} 2^{\prime} 16^{\prime \prime} \mathrm{W}$ & $\mathrm{T}+\mathrm{L}$ & 5205 & 12.24 \\
\hline Zanthoxylum rigidum Humb. \& Bonpl. ex Willd. & Rutaceae & $19^{\circ} 29^{\prime} 2 " \mathrm{~S} 57^{\circ} 2^{\prime} 16^{\prime \prime} \mathrm{W}$ & $T+L$ & 5200 & 12.88 \\
\hline
\end{tabular}

were visualized under UV (254 and $365 \mathrm{~nm}$ ), two bands were removed with Rf: 0.58 e Rf: 0.64 .

\section{HPLC-DAD-ESI-QTOF-MS/MS of Pm-EtOAc and active fractions}

$8 \mu \mathrm{L}$ of samples $(1 \mathrm{mg} / \mathrm{mL}$ ) was injected into the Shimadzu LC-20AD UFLC chromatograph, coupled to DAD and ESI-QTOF microTOF III (BrukerDaltonics ) in line, monitored between 240-800 nm, and operated in negative and positive mode (m/z 120-1200 and collision energy 45-65 V). The stationary phase was the Kinetex C-18 chromatography column (Phenomenex, $2.6 \mu, 150 \times 2.1 \mathrm{~mm}$ ) and a gradient elution of water (Phase $A$ ) and acetonitrile (Phase $B$ ) both with $1 \%$ acetic acid: $0-2$ min. $3 \%$ Phase $B ; 2-25$ min. 3-25\% Phase B; 25-35 min. 25-62\% Phase B, followed by column washing and reconditioning (11 min). Flow rate: $0.3 \mathrm{~mL} / \mathrm{min}$. Data were processed using Data Analysis software version 4.2 (Bruker), and compounds were identified based on ultraviolet spectra, retention time, and fragmentation profile compared to the literature.

\section{Statistical analysis}

Statistical significance in the disk diffusion test was determined using Kruskal-Wallis tests and Dunn's post-test ( $p \leq 0.05)$.

\section{Acknowledgment}

The authors thank the Instituto Adolfo Lutz (São Paulo) for the ATCC strains graciously supplied; to the technicians João Roberto Fabri, Amanda Galdi Boaretto, and Fernanda Luíza Espinosa Spositto for the operational laboratory support.
Conflicts of Interest

The authors declare no conflict of interest.

References

[1] Araújo SM, Fontes CJF, Leite Júnior DP, Hahn RC. Fungal agents in different anatomical sites in public health services in Cuiabá, State of Mato Grosso, Brazil. Rev Inst. Med Trop 2012; 54: 5-10

[2] Mattos K, Rodrigues LC, Oliveira KMP, Diniz PF, Marques LI, Araujo AA, Chang MR. Variability in the clinical distributions of Candida species and the emergence of azole-resistant non-Candida albicans species in public hospitals in the Midwest region of Brazil. Rev Soc Bras Med Trop 2017; 50: 843-847

[3] Pappas PG, Lionakis MS, Arendrup MC, Ostrosky-Zeichner L, Kullberg B]. Invasive candidiasis. Nat Rev Dis Primers 2018; 4: 18026

[4] Chen J, Tian S, Han X, Chu Y, Wang Q, Zhou B, Shang H. Is the superbug fungus really so scary? A systematic review and meta-analysis of global epidemiology and mortality of Candida auris. BMC Infect Dis 2020; 20: 827

[5] Ahangarkani F, Shokohi T, Rezai MS, Ilkit M, Mahmoodi Nesheli H, Karami H, Tamaddoni A, Alizadeh-Navaei R, Khodavaisy S, Meis JF, Badali H. Epidemiological features of nosocomial candidaemia in neonates, infants and children: A multicentre study in Iran. Mycoses 2020; 63: 382-394

[6] Bonfietti LX, Szeszs MW, Chang MR, Martins MA, Pukinskas SRBS, Nunes MO, Perreira GH, Paniago AMM, Purisco SU, Melhem MSC. Ten-Year study of species distribution and antifungal susceptibilities of Candida bloodstream isolates at a Brazilian tertiary hospital. Mycopathologia 2012; 174: 389-396 
[7] Colombo AL, Nucci M, Park B], Nouér SA, Arthington-Skaggs B, da Matta DA, Warnock D, Morgan J. Epidemiology of candidemia in Brazil: a nationwide sentinel surveillance of candidemia in eleven medical centers for the Brazilian network candidemia study. J Clin Microbiol 2006; 44: 2816-2823

[8] Arif T. Natural products - antifungal agents derived from plants. J Asian Nat Prod Res 2009; 11: 621-638

[9] Bieski IGC, Santos FR, Oliveira RM, Espinosa MM, Macedo M, Albuquerque UP, de Oliveira Martins DT. Ethnopharmacology of medicinal plants of the Pantanal region (Mato Grosso, Brazil). Evid Base Compl Alternative Med 2012; 2012: 1-36

[10] Evans TL, Costa M, Tomas WM, Camilo AR. Large-scale habitat mapping of the Brazilian Pantanal wetland: A synthetic aperture radar approach. Remote Sens Environ 2014; 155: 89-108

[11] Hoffmann JJ, Wiedhopf RM, Cole JR. Cytotoxic and tumor inhibitory agent from Polygala macradenia Gray (polygalaceae): 4'-demethyldeoxypodophyllotoxin. J Pharm Sci 1977; 66: 586-587

[12] Hokanson GC. Podophyllotoxin and 4'-demethylpodophyllotoxin from Polygala polygama (Polygalaceae). J Nat Prod 1978; 41: 497-498

[13] Huang IJ, Zhou LY, Wang JM, Li Q, Geng YY, Liu HY, Hua Y. Two new flavonol glycosides from Polygala sibirica L. var megalopha Fr. Molecules 2015; 20: 21494-21500

[14] Wu J, Chen S, Gao J, Wu L, Chen S, Tu P. Megastigmane glycosides from Polygala hongkongensis Hemsl. Chem Res Chinese U 2007; 23: $530-532$

[15] Moron J, Polonsky J, Pourrat H. Polygalaxanthones A and B, new isolated xanthones from Polygala paenea. Bull Sot Chim Fr 1967; 130-134

[16] Shi TX, Wang S, Zeng KW, Tu PF, Jiang Y. Inhibitory constituents from the aerial parts of Polygala tenuifolia on LPS-induced NO production in BV2 microglia cells. Bioorg Med Chem Lett 2013; 23: 5904-5908

[17] Tian LW, Pei Y, Zhang YJ, Wang YF, Yang CR. 7-O-Methylkaempferol and - quercetin Glycosides from the Whole Plant of NerWilia fordii. J Nat Prod 2009; 72: 1057-1060

[18] Zhan H T, Jian-feng WU, Hai-yan L, Hong-qi M, Xu-xin Z. Protective effect of flavonoids from Polygala hongkongensis on blood brain barrier in rats with focal cerebral ischemia reperfusion. J Apoplexy Nerv Dis 2012; 29: 1004-1007

[19] Saleem M, Kim H.J, Han CK, Jin C, Lee YS. Secondary metabolites from Opuntia ficus-indica var. saboten. Phytochemistry 2006; 67: 1390-1394

[20] Schliemann W, Schmidt J, Nimtz M., Wray V, Fester T, Strack D. Accumulation of apocarotenoids in mycorrhizal roots of Ornithogalum umbellatum. Phytochemistry 2006; 67: 1196-1205

[21] Deng X, Gao G, Zheng S, Li F. Qualitative and quantitative analysis of flavonoids in the leaves of Isatis indigatica Fort. by ultra-performance liquid chromatography with PDA and electrospray ionization tandem mass spectrometry detection. J Pharmaceut Biomed 2008; 48: 562-567

[22] Parejo I, Jauregui O, Nchez-Rabaneda F S, Viladomat F, Bastida J, Codina C. Separation and characterization of phenolic compounds in fennel (Foeniculum vulgare) using liquid chromatography-negative electrospray ionization tandem mass spectrometry. J Agric Food Chem 2004; 52: 3679-3687

[23] Luo Y, Wu S, Li X, Li P. LC-ESI-MS-MS Determination of rat plasma protein binding of major flavonoids of flos Lonicerae japonicae by centrifugal ultrafiltration. Chromatographia 2010; 72: 71-77

[24] Zhou Y, jiang SY, Ding LS, Cheng SW, Xu HX, But PPH, Shaw PC. Chemical Fingerprinting of Medicinal Plants "Gui-jiu" by LC-ESI Multiple-Stage MS. Chromatographia 2008; 68: 781-789

[25] Duan RG, Li JW, Zou JH, Li QH. Lignans constituents from callus culture of Dysosma versipellis. J Chin Pharm Sci 2014; 49: 1306-1309

[26] Meng-long Y, Zhong-liang C, Ze-sheng G, Yu-xiang X. Separation and identification of chemical constituents of Dysosma majorense. Acta Bot $\operatorname{Sin} 1990 ; 32: 45-48$
[27] Rybalchenko NP, Prylhodko VA, Nagorna SS, Volynets NN, Ostapchuk AN, Klochko VV, Rybalchenko TV, Avdeeva LV. In vitro antifungal activity of phenylheptatriyne from Bidens cernua L. against yeasts. Fitoterapia 2010; 81: 336-338

[28] Johann S, Mendes BG, Missau FC, Resende MA, Pizzolatti MG. Antifungal activity of five species of Polygala. Braz J Microbiol 2011; 42: 1065-1075

[29] Scorzoni L, Benaducci T, Almeida AMF, Silvia DHS, Bolzani VS, Gianinni MJSM. The use of standard methodology for determination of antifungal activity of natural products against medicinal yeasts Candida sp and Cryptococcus sp. Braz J Microbiol 2007; 38: 391-397

[30] Souza JME, Chang MR, Brito DZ, Farias KS, Damasceno-Junior GA, Turatti ICC, Lopes NP, Santos EA, Carollo CA. Antimicrobial activity of Aspilia latissimi (Asteraceae). Braz J Microbiol 2015; 46: 1103-1110

[31] Praxedes PG, Zerlin JK, Dias LO, Pessoni RAB. A novel antifungal protein from seeds of Sesbania virgata (Cav.) Pers. (Leguminosae-Faboideae). Braz J Biol 2011; 71: 687-692

[32] Rojas A, Hernandez L, Pereda-Miranda R, Mata R. Screening for antimicrobial activity of crude drug extract and pure natural products from Mexican medicinal plants. J Ethnopharmacol 1992; 5: 275-283

[33] Pauli A. Anticandidal low molecular compounds from higher plants with special reference to compounds from essential oils. Med Res Rev 2006; 26: 223-268

[34] Vuuren SF, Naidoo D. An antimicrobial investigation of plants used traditionally in southern Africa to treat sexually transmitted infections. J. Ethnopharmacol 2010; 130: 552-558

[35] Cleveland AA, Farley MM, Harrison LH, Stein B, Hollick R, Lockhart SR, Magill SS, Derado G, Park BJ, Chiller TM. Changes in incidence and antifungal drug resistance in candidemia: results from populationbased laboratory surveillance in Atlanta and Baltimore, 2008-2011. Clin Infect Dis 2012; 55: 1352-1361

[36] Scorzoni L, de Lucas MP, Mesa-Arango AC, Fusco-Almeida AM, Lozano E, Cuenca-Estrella M, Mendes-Giannini M], Zaragoza O. Antifungal efficacy during Candida krusei infection in non-conventional models correlates with the yeast in vitro susceptibility profile. PLoS One 2013; 8: 60047

[37] Seleem D, Pardi V, Murata RM. Review of flavonoids: A diverse group of natural compounds with anti-Candida albicans activity in vitro. Archives of Oral Biology 2016; 76: 76-83

[38] Vogt V, Cifuente D, Tonn C, Sabini L, Rosas S. Antifungal activity in vitro and in vivo of extracts and lignans isolated from Larrea divaricata Cav. against phytopathogenic fungus. Ind Crop Prod 2013; 42: 583-586

[39] Petrova A, Popova M, Kuzmanova C, Tsvetkova I, Naydenski H, Muli E, Bankova V. New biologically active compounds from Kenyan propolis. Fitoterapia 2010; 81: 509-514

[40] Gordaliza M, Garcıa PA, Del Corral JM, Castro MA, Gómez-Zurita MA. Podophyllotoxin: distribution, sources, applications and new cytotoxic derivatives. Toxicon 2004; 44: 441-459

[41] Richter BE, Jones BA, Ezzell JL, Porter N. Accelerated solvent extraction: A technique for sample preparation. Anal Chem 1996; 68: 1033-1039

[42] Clinical and Laboratory Standards Institute (CLSI). Reference method for broth dilution antifungal susceptibility testing of yeasts; forty informational supplement. CLSI document M27-S4. Clinical and Laboratory Standards Institute; 2012

[43] Clinical and Laboratory Standards Institute (CLSI). Reference method for broth dilution antifungal susceptibility testing of yeasts. Approved Standard, third edition. CLSI document M27-A3. Wayne: Clinical and Laboratory Standards Institute; 2008

[44] Rahalison L, Hamburger M, Monod M, Hostettmann K. Antifungal tests in phytochemical investigations: comparison of bioautographic methods using phytopathogenic and human pathogenic fungi. Planta Med 1993; 60: 41-44 